\title{
Islamic Legal Canons as Memes
}

\author{
Intisar A. Rabb* \\ Harvard Law School
}

\begin{abstract}
In her essay concluding the Roundtable, Intisar Rabb invites us to conduct a thought experiment - to think of legal canons as memes, that is, as cultural elements in circulation that, like genes, self-replicate and accrue to the benefit of human society. Just as memes spread, so do legal canons-principles that guide legal interpretation-from one scholar to another, from one written record to the other. Describing at length multiple angles from which legal canons can be categorized, Rabb shows that the many and varied types of canons illustrate how deeply embedded canons are in the social, cultural, and also legal culture that produces them. That, in turn, invites close collaboration between legal historians and data scientists to enable a mapping of a "meme pool" for legal canons, which she pursues through developing the Courts \& Canons project at Harvard Law School: through digital tools, we will be able to trace the curious textual travels of legal canons (as memes), and through that, the transmission of cultures, practices, and ideas in through all manner of texts (their meme pool) recording the history and practice of law and society in the Muslim world.

* Acknowledgments: I am grateful to the editors of the Islamic Law Blog for their critical comments and edits; to conversations this year with colleagues working at the intersection of Islamic history and digital humanities / data science-including Sarah Savant, who suggested winged words as another apt metaphor; and to faculty colleagues and students who participated in and offered insightful comments about an earlier version of this essay at the Harvard History Department Seminar on February 23, 2021.
\end{abstract}




\section{INTRODUCTION}

We've all seen memes, and we've seen them in various guises in the internet's most recent forms. There are viral memes, like a down-home Bernie Sanders sitting on a folding chair in hand-made mittens at this year's Inauguration in Washington DC, or the wide-eyed "I'm not a cat" lawyer blooper from Texas. We've seen fleeting memes, like Gangnam style K-pop videos (with nearly $4 \mathrm{~b}$ views today), and long-lasting memes, like rickrolling American-pop videos (ranked by Reddit as the longest standing meme today).

I'D LIKE TO PROPOSE A LEGAL HISTORY THOUGHT EXPERIMENT WITH A DIGITAL HUMANITIES EDGE: I SUGGEST THINKING OF LEGAL CANONS AS MEMES, AND PROPOSE THAT MINING A TEXTUAL "MEME POOL" WITH THE HELP OF DATA SCIENCE TOOLS CAN HELP UNCOVER IMPORTANT INSIGHTS IN LEGAL HISTORY IN WAYS THAT CANONS ARE REMARKABLY WELL SITUATED TO DO. This idea applies to contexts of both American law and Islamic legal history. But, aside from some comparative framing, I will focus on Islamic legal history in tune with this Roundtable's focus and in line with my own work on Islamic legal canons (qawä id fiqhiyya) as sources for social and legal history. To proceed along these thought-experimental lines requires defining three concepts: (1) memes, (2) Islamic legal canons, and (3) meme pools in this context: sources for both Islamic interpretive-legal doctrine and social-legal history - to which I will turn after providing a little more background on the general idea.

Now to state up front: the legal canons-as-memes I'm interested in referring to a legal term of art-also known as "legal maxims," "canons of construction," or "principles of interpretation"-common to many legal systems where judges and jurists interpret law. Legal canons are notoriously difficult to define. But there is a core, often aided by work that jurists do in collecting them. ${ }^{10}$ Black's Law Dictionary defines canon or maxim

10 For examples of collections, in American law, see those of Antonin Scalia and Bryan Garner in a treatise called Reading Law (St. Paul, MN: Thompson/West, 2012), 69-77 (collecting 57 "textualist canons" that ought to guide courts) 
as "an established principle or proposition; a principle of law universally admitted, as being a correct statement of the law, or as agreeable to natural reason." "In American law, legal canons then are statements or guidelines for interpretation-sometimes incorporating the Latin from Roman law-like one version of the so-called rule of lenity: "in dubio pro reo: when in doubt, [decide] in favor of the defendant" or the ordinary meaning canon: "words are to be understood in their ordinary, everyday meanings - unless the context indicates that they bear a technical sense."12 Scholars of Islamic law typically define canons as interpretive principles that "used to apply general Islamic laws to particular cases." ${ }^{13}$ But this is the oft-repeated medieval defi-

that and those of William N. Eskridge, Jr. in a response treatise called Interpreting Law (St. Paul, MN: Foundation Press, 2016) (collecting "dynamic canons" culled from Supreme Court cases from 1986 to 2016). Neither work ventures a short definition of legal canons. For the attendant difficulties that come with defining what counts as a canon, problems of "overcanonization," and challenges in distinguishing canons from mere doctrines or patterns of judicial-legal reasoning, see the thoughtful book review of Interpreting Law by Anita S. Krishnakumar and Victoria F. Nourse, “The Canon Wars," Texas Law Review 97, no. 1 (2018): 163-91.

11 Bryan A. Garner and Henry Campbell Black, Black's Law Dictionary, 11 ed. (St. Paul, MN: Thomson Reuters, 2019), s.v. "legal maxim." For newly available video definitions, see general definitions of legal maxims on Audiopedia (2016), and definitions of key maxims of criminal law by Dean Ralph Sarmiento (2019).

12 See Scalia and Garner, Reading Law, canon 6: 69-77 (ordinary-meaning canon); canon 49: 296-302 (rule of lenity); cf. Eskridge, Interpreting Law, 407 (ordinary meaning rule), 430 (rule of lenity). Of particular interest in my own work, the modern American rule of lenity is a statutory principle of strict construction specifying that, for ambiguous criminal law statutes, choose the narrower interpretation in favor of the defendant." See now Shon Hopwood, "Restoring the Historical Rule of Lenity as a Canon," New York University Law Review 95, no. 4 (2020): 918-51; Intisar A. Rabb, "The Appellate Rule of Lenity," Harvard Law Review Forum 179, no. 8 (2018): 179-215. For recent work assessing the "ordinary meaning" canon against empirically measured ordinary meaning, see Kevin Tobia, Brian G. Slocum, Victoria Nourse, "Statutory Interpretation from the Outside," Columbia Law Review (forthcoming).

13 For examples of contemporary treatments that reproduce common medieval definitions, see Ya' qūb b. 'Abd al-Wahhāb Bā Husayn, al-Qawā 'id, al-fiqhiyya: al-Mabādi', al-muqawwimāt, al-mașādir, al-dalīliyya, al-tațawwur (Riyadh: Maktabat al-Rushd, 1998), 22: al-amr al-kulli yanțabiq 'alayhi juz'iyyāt kathīra tufham aḥkāmuhā minhā (quoting Tāj al-Dīn ibn al-Subkī); Wolfhart Heinrichs, "Kawāid Fikhiyya," $E I^{2}$-Supplement [Online] (defining qawā'id fiqhiyya as "madhhab-internal legal guidelines that are applicable to a number of particular cases in various fields of the law, whereby the legal determinations $(a h k \bar{a} m)$ of these cases can be derived from these principles"). 
nition that does not provide an adequate definition to the range of ways canons are collected and used. In Islamic law, canons are comparable statements or guidelines of interpretation that sometimes coincide with Latin and U.S. canons, and they are sometimes unique. Examples are the analogous Islamic rule of lenity or "doubt canon," "idra' $\bar{u}$ al-hudüd bi'l-shubahāt: avoid criminal punishments in cases of doubt," and the analogous ordinary meaning canon, establishing "așālat al-z̧uhūr: a presumption of ordinary meaning;" as well as the unique permissibility canon, "al-aṣl fì'l al-ashyā' al-ibăha: the presumption for legal acts is permissibility." 14

Moreover, legal canons have functions just as hard to capture. Legal canons are good pedagogical tools, and they are used as such. But their pithy form belies their expansive capture of whole areas of law, or the extent to which they are also used for much more: gap-fillers, tie-breakers, value-reinforcers, and other functions. Legal canons are good pedagogical tools, and used as such - their pithy form belies their expansive capture of whole areas of law; but they are also used for much more. Rather than settle on a definition or function in the abstract, and following the bottom-up approach of the modern American and medieval Muslim scholars collecting canons, I treat as a canon any principle that the scholars who collected legal canons identified from actual usage in legal and judicial contexts historically; and propose looking to see how they function inside and outside of those circles. ${ }^{15}$

14 On the lenity rule and doubt canon in Islamic law, see my book on Doubt in Islamic Law: A History of Legal Maxims, Interpretation, and Islamic Criminal Law (Cambridge: Cambridge University Press, 2015). For various aspects of these principles see also my articles on "Reasonable Doubt" in Islamic Law." Yale Journal of International Law 40 (2015): 41-94, "The Islamic Rule of Lenity," Vanderbilt Journal of Transnational Law 44, no. 5 (2011): 1299-1351; and "Islamic Legal Maxims as Substantive Canons of Construction: Hudūd-Avoidance in Cases of Doubt," Islamic Law and Society 17 (2010): 63-125. On the ordinary meaning canon and permissibility presumption, see below, notes $25-33$ and accompanying text.

15 I provide more detail about what this means in the second and third Parts of this essay. For examples of Islamic law collections of canons, in addition to the modern and medieval sources cited in Part Two, see, e.g., Shihāb al-Dīn al-Qarāfī (d. 684/1285), Furūq, ed. 'Umar Qīyām and Qāsim b. 'Abd Allāh Ibn al-Shāțt (Beirut: Mu'assasat al-Risāla, 2003), Ibn Rajab al-Ḥanbalī (d. 795/1393), al-Qawā 'id 
This thought experiment comes with three observations: First, the category of Islamic legal canons is the third of three major genres in Islamic law (following furü al-fiqh and $u s \underline{u} l$ al-figh), such that studying them bears promise for major research insights. But legal canons are understudied and, with some exceptions, we still don't have a cogent picture of their collective historical trajectory, institutional functions, or societal use. Exceptions include studies in this part of the world only since about the turn of the century. ${ }^{16}$ Those studies add to encyclopedic studies and published editions of canons collections from the Muslim world over the past half century. ${ }^{17}$ Second,

fì al-fiqh al-Islāmī, 2nd ed. (Mecca: n..p., 1999); al-Fāḍil al-Miqdād al-Suyūrī (d. 826/1423), Naḍd al-qawā'id al-fiqhiyya 'alā madhhab al-imāmiyya, ed. by 'Abd al-Lațîf al-Kūhkamarī Mạmmūd al-Mar' ashī (Qum: Maktabat Āyat Allāh al-'Uẓmā al-Mar'ashī, 1403/1982-3); Jalāl al-Dīn al- Suyūțī (d. 911/1505), al-Ashbāh wa'lnaz $\bar{a}$ 'ir, ed. Muhammad al-Mu tașim billāh al-Baghdādī (Beirut: Dār al-Kitāb al'Arabī, 1998); Ibn Nujaym (d. 970/1563), Al-ashbāh wa'l-nażā'ir, ed. Muḥammad Muțî‘ al-Ḥāfiz (Damascus: Dār al-Fikr, 1983).

16 In addition to my study of legal canons in Doubt IN IsLamic Law, which follows a representative canon throughout medieval Islamic history and provides a short history of legal canons, some recent studies include Mariam Sheibani, "Innovation, Influence, and Borrowing in Mamlūk-Era Legal Maxim Collections: The Case of Ibn 'Abd al-Salām and al-Qarāfî," JAOS 140, no. 4 (2020): 907-53 (with a useful collection of 17 legal canons, or "maxims" discussed in the article at 946-51); Khadiga Musa, "Legal Maxims as a Genre of Islamic Law," Islamic Law and Society 21 (2014): 325-65; Mohammad Hashim Kamali, "Legal Maxims and Other Genres of Literature in Islamic Jurisprudence," Arab Law Quarterly 20, no. 1 (2006 ): 77-101; Wolfhart Heinrichs, "Qawā 'id as a Genre of Legal Literature," in Studies in Islamic Legal Theory, ed. Bernard Weiss (Leiden: Brill, 2002): 366-84. Necmettin Kizılkaya has a forthcoming book on Legal Maxims in Islamic Law: Concept, History, and Applications of Axioms of Juristic Accumulation (Leiden: Brill, forthcoming 2021), and prior works in Turkish and in English telegraphing his views: e.g., "Legal Maxims," in The Encyclopedia of Islamic Bioethics, ed. Ayman Shabana (OxFord Islamic Studies Online). Much earlier, the "ubiquitous" Joseph Schacht had roughhewn thoughts about Islamic legal maxims as well in chapter 6 of his Origins of Muhammadan Jurisprudence (Oxford: Clarendon Press, 1950), 180-89.

17 To take just a few, which would be good starting places for anyone interested in pursuing the study of one or more legal canons, see, e.g., Muhammad Șidqī Būrnū, Mawsū 'at al-qawā 'id al-fiqhiyya, 3rd ed. (Beirut: Dār al-Risāla al- 'Ālamiyya, 2015); Maḥmūd Mușțafā 'Abbūd Harmūsh, Mu 'jam al-qawā 'id al-fiqhiyya al-Ibāọiyya, ed. Riḍ̂ān al-Sayyid (Muscat: Wizārat al-Awqāf wa'l-Shu'ūn al-Islāmiyya, 2010); Muḥammad Mușțafā al-Zuḥaylī, al-Qawā id al-fiqhiyya wa-tațbìqatuhā fì almadhāhib al-arba'a (Damascus, 2006); Muḥammad Ḥasan al- Bujnūrdī, al-Qawā 'id al-fiqhiyya, ed. Mahdī al-Mihrīzī and Muhammad Ḥusayn al-Dirāytī (Qum: Dalīl-i Mā 1424/2003-4); Muștafāa Muhaqqiq Dāmād, Qavā id-i fiqh (Tehran: Markaz-i Nashr-i 
as this Roundtable has reflected, with a problem common to any field of legal history, there are two sometimes opposing approaches based on the sources: studies drawing on self-conscious law/doctrinal sources for intellectual legal history, and studies drawing on historical/prosopographical writing on social legal history. Third, this approach offers a way to harness the power of new tools in digital humanities and data science to see in historical and legal sources what would be impossible for a human alone.

\section{What Exactly is a Meme?}

Merriam-Webster defines a meme as "an idea, behavior, style, or usage that spreads from person to person within a culture." ${ }^{18}$ The term is relatively new - coined in 1978 and not to appear in the Oxford English Dictionary until 1989, as follows: "A cultural element or behavioural trait whose transmission and consequent persistence in a population, although occurring by non-genetic means (esp. imitation), is considered as analogous to the inheritance of a gene." 19 The concept "meme," as new as it is, and "like any good meme, caught on fairly quickly, spreading from person to person as it established itself in the language." 20 As it turns out, British scientist Richard Dawkins invented the term relatively recently in his 1976 book, The Selfish Gene, wherein he sought to portray the gene within each human being as a "survival machine." ${ }^{21}$ Our survival comes partly through

'Ulūm-i Islāmī, 1378/1999-2000); Ya qūb b. 'Abd al-Wahhāb al-Bā Ḥusayn, alQawā'id al-fiqhiyya: al-mabādi', al-muqawwimāt, al-mașādir al-dalīliyya, al-tațawwur-Dirāsa nazariyya tahlīliyya ta sīliyya ta'rīkhiyya (Riyadh: Maktabat al-Rushd, 1998).

18 Merriam-Webster Dictionary [Online], s.v. meme. See also Richard Dawkins, The Selfish Gene, reprinted with corrections (New York: Oxford University Press, 1978), 206 (“'Mimeme' comes from a suitable Greek root, but I want a monosyllable that sounds a bit like 'gene.' I hope my classicist friends will forgive me if I abbreviate 'mimeme' to 'meme."' (quoted above)).

19 See the University of Chicago, Theories of Media: Keywords GlosSARY (2004), s.v. "meme."

20 Merriam-Webster Dictionary, s.v. "meme."

21 Richard Dawkins, The Selfish Gene, Reprinted with corrections. ed. (New York: Oxford University Press, 1978), $203 \mathrm{ff}$. 
genes - which drives biological evolution and the requirements for material survival by choosing paths selfishly that will lead to its self-perpetuation. And survival comes partly through memes - which refer to cultural and linguistic evolution and the requirements for other aspects of survival. In fact, Dawkins calls memes an essential component of human evolution itself-over and above genes. They are essential because, like genes, they are replicating entities that evolve, and accrue to the benefit of human society. ${ }^{22}$ Dawkins puts it this way: "Just as genes propagate themselves in the gene pool by leaping from body to body via sperm or eggs, so memes propagate themselves in the meme pool by leaping from brain to brain via a process which, in the broad sense, can be called imitation." ${ }^{23}$ Perhaps anticipating the fleeting and permanent nature of the internet version of memes as well as the historical roots of religious-legal memes, Dawkins observed that: "some memes, like genes, achieve brilliant, shortterm success in spreading rapidly, but do not last long in the meme pool. Others, such as Jewish religious laws, may continue to propagate themselves for thousands of years ...."24

Here, I want to suggest three things: (a) I suggest that Islamic legal canons can function as memes, (b) I offer a typology for memes to offer a common grammar for identifying them, as they arose as an independent genre and took on a certain institutional role in the thirteenth century Islamic world, and (c) I suggest that legal canons-as-memes offer a means to bridge the typically divided social-historical from doctrinal-legal sources to offer new approaches to the study of Islamic legal history, and propose ways of doing so computationally.

To be sure, the analogy of legal canons to memes is not precise, and there are reasons to think it might be ill-advised if hewing too close to Dawkins' original notion of selfish genes.

22 Ibid., 205 (calling both replicators).

23 Ibid., 206.

24 Ibid., 209. I have omitted the second part of the sentence, "usually because of the great permanence of written records," because I disagree that memes (as, say, legal doctrines, constitutions, or canons) perpetuate because they are written. Often, they are not written, at least not for long stretches of time. It just so happens that we are able to take advantage of text-mining for canons as memes because they now are. 
Memes for him are selfish; I don't presume Islamic legal canons are. Memes for him have a much broader scope - they could be a doctrine or idea or God himself; I mean the specific term of art of legal canons that we know of in American, Islamic, and Roman law - as a subset perhaps of his broader notion. ${ }^{25}$ And then there is the question of human agency and legal, social, and moral values that extend from it. His theory has problems that arise when selfishness is contrasted with altruism; and while memes are self-perpetuating, it is not clear that memes are, in fact, selfish. In fact, as Dawkins himself alludes to in the last pages of his book, precisely the fact of human agency in the perpetuation of memes is instructive. I think it will be particularly instructive in these types of memes: Islamic legal canons. There is enough in the historical record to indicate that at least some are decidedly unselfish, and pair more often than not with decisions about morality, spirituality, and values in ways that genes may not. My hunch is that we will see in Islamic legal canons a meme-propagation that survives for some of the typical "selfish" reasons of, say, law-and-economics models of efficiency, wealth maximization, and power concentration. But my hunch is also that we'll see survival for more of the unselfish bases for law than the ones we are used to discussing in law schools where we strictly separate law from morality. It could be that the whole effort of examining legal canons as memes will be best suited to show whether and which values - beyond selfishness - account for their perpetuation and role in the history of Islamic law and society.

25 In Dawkins' broad view, "Examples of memes are tunes, ideas, catch phrases, clothes fashions, ways of making pots or building arches;" and claimed that even God is a meme: "How does it replicate itself? By the spoken and written word, aided by great music and art. ... What is it about the idea of god that gives it its stability and penetrance in the cultural environment? The survival of the god meme in the meme pool results from its great psychological appeal. [In part] ... it suggests that injustices in this world may be rectified in the next. ... God exists, if only in the form of a meme with high survival value ... in the environment provided by human culture."

Dawkins, The Selfish Gene, 206. 


\section{What are Islamic Legal Canons?: A typology}

Islamic legal canons are interpretive principles that represent varied conceptions of Islamic law and its values, as they developed over time and space. ${ }^{26}$ Scholars of Islamic law - both medieval and modern - have typically defined these legal canons narrowly, as text-basedprinciples used to apply general Islamic laws to particular cases ${ }^{27}$ Having emerged at the start of Islam's history in the seventh century, Islamic legal canons have played a major role in the construction of Islamic law and society ever since. ${ }^{28}$ The canons come from both the classical enumeration of four foundational sources (Qur' ān, Sunna, consensus, and legal reasoning) and from juristic and judicial practices addressing local disputes, responding to political authority and encapsulating social-cultural norms. Throughout Islam's history, judges and jurists have used legal canons not only to restate Islamic law, but to construct it. In the process, they deposited into the corpus of canons their ideas of valid interpretive and procedural principles, social-moral values, and the scope of their own power vis-à-vis other institutional actors.

Studying legal canons may well be essential to understanding Islamic law because the canons offer a wide-angled lens through which scholars can examine the history of Islamic law in terms of substance and procedure, textual and contextual bases for the law, and hidden values affecting legal institutions as well as elite or ordinary people. Moreover, a legal canons lens spotlights the tremendous degree of judicial discretion, interpretive diversity, and legal change permeating Islamic legal history. Enterprising jurists in the Muslim world have taken up

26 This section draws mainly from and offers a summarized portion of my chapter on Interpreting Islamic Law through Legal Canons, in RoutLedge HaNDвоOK OF Islamic LaW, ed. Khaled Abou El Faḍl et al. (Abington: Routledge, 2019).

27 See, as quoted above, note 4, Bā Husayn, al-Qawāid, al-fiqhiyya, 22: al-amr al-kullī yantabiq 'alayhi juz'iyyāt kathīra tufham ạ̣kāmuhā min$h \bar{a}$ (quoting Tāj al-Dīn ibn al-Subkī).

28 For a history, see my Doubt in Islamic Law, 348-57. 
the study of legal canons in recent decades, but they complain that attempts to define and classify these canons have not been precise or comprehensive..$^{29}$ A close look at legal canons will be instructive, and all the better with tools to facilitate that task.

Scholars of Islamic law, both medieval and modern, typically classify legal canons according to scope and general function for a jurist: INTERPRETIVE, SUBSTANTIVE, and UNIVERSAL. The first two categories follow the divisions between $u s \underline{u} l$ al-fiqh (interpretive norms) and furü 'al-fiqh (substantive laws); and the third category is a tenth-century addition by jurists to the substantive canons list meant to highlight the five agreed-upon ("universal") values derived deductively from Islamic law's aggregate rulings. Drawing on this basic rubric, but in attempt to offer a more streamlined typology of canons that follows juristic treatment of them (with updated insights from modern statutory interpretation theory), I collapse universal into substantive canons and add three additional categories that reflect the full spectrum of canons with respect to scope, function, and institutional role historically. The categories that I propose are these: SUBSTANTIVE, INTERPRETIVE, PROCEDURAL, GOVERNANCE, and STRUCTURAL. Without detracting from the basic accounts of the content or range of Islamic legal canons, this rubric allows us to classify and assess legal canons in ways that better account for their historical significance, broader range, and varied functions - that is, the ways in which canons have been deployed in Islamic law and society over time..$^{30}$

29 For instance, al-Sayyid Muhammad Ḥasan Bujnūrdī, al-Qawā id al-fiqhiyya (Qum, Iran: al-Hādī, 1419/[1998]), 15.

30 For common classification schemes, see, for example, Abu 'Abd Allāh al-Maqqarī, Qawā id, ed. Aḥmad b. 'Abd Allāh b. Hamīd (Mecca, Saudi Arabia: Jāmi 'at Umm al-Qurā, 198-), 198-212; Suyūrī, Nadd al-qawā id al-fiqhiyya, 90114; Ibn Nujaym, al-Ashbāh wal-naz̧ā'ir, 1:17-19; Muḥammad al-Husayn Āl Kāshif al-Ghițā', Tahrīr al-Majalla, ed. Muhammad Mahdī al-Āṣifī and Muhammad alSā idī (Qum, Iran: al-Majma ' al- 'Ālamī lil-Taqrīb Bayna al-Madhāhib al-Islāmiyya, 1422/2001-2), 1:129-32, 139-42, 153-56. This section draws on and supplements those sources. 


\section{SUbSTANTIVE CANONS: UNIVERSAL, GENERAL, SPECIFIC}

Substantive canons elaborate basic substantive principles of law as concise restatements designed to provide guidance in the form of presumptions, tie-breakers, or clear statement rules to aid in interpretation and application of rulings in major areas of Islamic law. These canons often reflect value judgements about privacy, property, and questions of public norms. Whereas in U.S. legal canons come from the old common law or from American constitutional or statutory texts and judicial precedents ${ }^{31}$ Islamic law's substantive canons are drawn from both foundational texts and societal norms as understood by jurists and judges:

1.1 a small set of universal canons (qawā id kulliyya) said to apply to all of Islamic law, almost as policy preferences;

Harm is to be removed [or: no harm]: al-darar yuzāl [la darar wa-lā dirār $]$.

Custom is legally authoritative: al- 'āda muhakkama.

Hardship requires accommodation [of strict legal rules]: al-mashaqqa tajlibu al-taysīr .

Certainty is not superseded by doubt: al-yaqīn la yazūlu bi-l-shakk.

Acts are to be evaluated according to their aims: al-umūr bi-maqāṣidihā.

1.2 thousands of general canons (qawà id fiqhiyya 'àmma) that have wide application but that tolerate some exceptions; and

1.3 even more specific canons (dawābit, qawā id fiqhiyya juz'iyya) that apply to particular subject areas of law with more limited scope.

31 To compare the American law notion of substantive canons, see William N. Eskridge, Jr., "The New Textualism and Normative Canons," Columbia Law Review 113, no. 513 (2013): 537 ("Substantive canons are presumptions, clear statement rules, or even super-strong clear statement rules that reflect judicial value judgments drawn from the common law and from constitutional law (created by judges), as well as from statutes themselves (as understood and interpreted by judges)....”). 


\section{INTERPRETIVE CANONS}

Interpretive canons aim to guide judges and jurists on how to interpret foundational texts when devising new legal rulings or otherwise issuing opinions on novel legal issues: ${ }^{32}$

2.1 Textual canons (linguistic rules for how to interpret texts) instruct jurists and judges on how to interpret Islam's foundational texts to apply the "ordinary meaning," ${ }^{33}$ based on common-sense rules of grammar and style. ${ }^{34}$ An example is the ordinary meaning canon instructing judges to adopt the ordinary or apparent meaning unless there is some indication otherwise. ${ }^{35}$

2.2 Source-preference canons specify how judges and jurists should choose among multiple and/or conflicting sources addressing the same legal issue. Examples are canons privileging foundational texts over interpretive rules ${ }^{36}$ custom

32 See Bujnūrdī, al-Qawā 'id al-fiqhiyya, 135 (i.e., interpretive canons are for the mujtahid rather than the muqallid).

33 On "ordinary meaning" and the related "objectified intent" in American law, in addition to Scalia and Garner, Reading Law, 69-77 and the sources in note 3 above, see John Manning, "Textualism and Legislative Intent," Virginia Law Review 91 (2005): 424 (defining "objectified intent" as the "import that a reasonable person conversant with applicable social and linguistic conventions would attach to the enacted words" that textualists typically apply); Ryan D. Doerfler, "Who Cares How Congress Really Works," Duke Law Journal 66 (2017): 983 (building on notions of objectified intent through analyses in linguistic philosophy with emphasis on context as salient information to both author and audience).

34 For English translations of ușül al-fiqh literature specifying grammatical rules of interpretation, see Bernard Weiss, The Search for God's Law: Islamic Jurisprudence in the Writings of Sayf al-Din al-Ämidī (Salt Lake City: University of Utah, 1992) (a translation and exposition of Sayf al-Dīn al-Āmidī’s al-Ihkām fì ușūl alahkām); Roy Mottahedeh, Lessons in Islamic Jurisprudence (Oxford: Oneworld, 2003) (a translation and commentary on Muhammad Bāqir al-Ṣadr's, Durūs fì 'ilm al-ușūl).

35 For discussion, see, e.g., Taskhīrī et al., Qawā id, 1:41-42 (aṣālat alzuhūr: presumption of apparent or prima facie meaning); 1:38-42 ('alāmāt al-ḥaqìqa: indications of ordinary meaning over figurative meeting). For canons on Islamic "legal meaning," by which a word assumes a technical meaning by conventional use in juristic discussions, see ibid., 1:28-31 (thubüt al-haqīqa al-shar 'iyya: presumption of Islamic legal meaning).

36 See, e.g., Būrnū, Mawsū'a, 39 (lā ijtihād ma'a al-nașș); Maḥmașānī, Falsafat al-tashrī', 225-26 (lā masāgha li-l-ijtihād fì mawrid al-nașs); Taskhīrì et al., Qawā 'id, 1:425-75 (section on: taqdīm al-nașs 'alā al-zāhir; tahkìm 
over contract, ${ }^{37}$ and the first-in-time opinion over another equally valid opinion..$^{38}$

2.3 Extra-textual canons. Extra-textual canons refer to presumptions and other principles of interpretation in matters where the foundational texts yield absurd results or no result at all. ${ }^{39}$ An example is the universal canon specifying that custom has legal authority and the related canon stipulating that there is no bar on changes in legal rulings with changes in the times. ${ }^{40}$ Some legal presumptions in this category operate as default rules in cases of silence of the text. Sunnī law, for example, specifies a presumption of permissibility for transactions, and a presumption of impermissibility for devotional acts or in matters of sexual ethics. ${ }^{41}$ Likewise, Shī $\mathbf{1}$ law includes a set of procedural presumptions designed to guide jurists to an outcome where texts are silent or ambiguous. ${ }^{42}$

al-naș̣s 'alā al-ẓāhir); Kamali, "Legal Maxims," 81 ("[I]jtihād does not apply in the presence of nașs [text].").

37 Many canons on custom relate to the universal canon regarding it: "custom has legal authority: al- 'àda muhakkama" (Mecelle, art. 36). For discussion of subsidiary canons, see Kamali, "Legal Maxims," 88-9: "what is determined by custom is tantamount to a contractual stipulation: al-ma 'rüf 'urfan ka-l-mashrüt sharțan" (Mecelle, art. 43).

38 Būrnū, Mawsū 'a, 28 (al-ijtihād lā yunqaḍ bi-mithlih).

39 In Sunnī law, extra-textual canons mirror the equitable "sources" in the lexicon of Sunnī jurisprudence: istiṣlāh, istihsānn and istișhāb, as well as, 'urf. In fact, one contemporary scholar has suggested that early accommodation for analogical reasoning and equitable principles facilitated the development of the field of legal canons in Sunni law much earlier than Shī'ì law. Bujnūrdī, al-Qawā 'id al-fiqhiyya, 9.

40 Maḥmașānī, Falsafat al-tashrī', 235. See Mecelle, art. 36 (al-' 'ada muḥakkama), art. 39 (lā yunkar taghayyur al-ậkām bi-taghayyur al-azmān).

41 See, e.g., Mạ̣mașān̄̄, Falsafat al-tashrī’, 219-20 (citing Asnawī, Sharh al-Manāhij, 3:108: al-aṣl fì al-manāfi al-ibāha wa-fì al-mafāsid alman' (the principle in matters of benefit is permissibility and in harm prohibition)); Kamali, "Legal Maxims," 84.

42 For an introduction, see Șadr, Durūs fì 'ilm al-ușūl, in Mottahedeh (trans.), Lessons in Islamic Jurisprudence, 119-33, 165-69. Like their Sunnī counterparts, Shī $\overline{1}$ jurists insist that these extra-textual canons were themselves derived from aggregated rulings. See, e.g., Makārim-Shīrāzī, Qawā id, 52. He also notes (p. 22) the differences between jurisprudential subjects and legal canons subjects - and that discussions of hujjiyyat al-istișhāb fì '-l-shubahāt al-mawdū iyya or albarā'a or wa'l-ihtiyāt al-jāriyatān fîha are the latter because they yield individual rulings and obligations (ahkām and waza'if shakhsiyya), not general principles for deriving them. 


\section{Procedural canons:}

\section{EVIDENCE AND JUDICIAL PROCEEDINGS}

Procedural canons are typically undifferentiated from the substantive canons in much of the existing legal literature on Islamic legal canons. But following medieval treatments of them in the broader historical literature, I treat them separately: jurists and judges used them to govern questions that arose with respect to evidence and court proceedings, rather than questions relating to specific questions of substantive law or jurisprudence:

3.1 Evidentiary canons help judges allocate burdens of proof for deciding cases, and they encapsulate evidentiary procedures common in judicial practice. The best known evidentiary canon is the principle placing the burden of proof on the petitioner: the burden of proof is on the claimant and the respondent may swear an oath of denial. ${ }^{43}$

3.2 Court procedure canons advise litigants on how to properly bring cases and judges on how to adjudicate them. Think: issues of standing, personal status, or sufficiency of evidence to entitle a person with a grievance to petition courts in the first place. Examples include rules that stipulate different outcomes based on identitarian norms, such as the canons governing non-Muslims in medieval Islamic lands: Non-Muslim testimony is accepted for cases involving non-Muslims, ${ }^{44}$ or canons reflecting rulings stipulating two women's testimony for that of one man. ${ }^{45}$

3.3 Judicial conduct canons detail rules of conduct for judges-often without specific inclusion in legal canons collections - such as the need to consult expert jurists when uncertain about questions of law, issues of demeanor, and causes for removal. For instance, judges were to avoid deciding cases

43 Mecelle, art. 76 (al-bayyina 'alā al-mudda ‘̀ wal-yamīn 'alā man ankar).

44 Ibid., 481 (contested canon).

45 For discussion of evidentiary disparities between men and women's court testimony, see Mohammad Fadel, "Two Women, One Man: Knowledge, Power and Gender in Medieval Sunni Legal Thought," International Journal of Middle East Studies 29 (1997): 185-204. 
when angry and could be dismissed 'for cause'. ${ }^{46}$

\section{Governance CANONS}

Governance canons are principles that reflect and encapsulate varied theories of Islamic public law and political-legal authority (siyāsa shar'iyya). They govern such matters as the authority to set and enforce rules of public law-criminal law, taxation, war, and the like. These canons also create avenues for the state or executive agent to issue equitable judgments beyond the four corners of the law. Examples (albeit contested) include:

canons allowing delegation of legal authority to the political ruler to resolve contested issues of law: it is for the imām to determine the extent of discretionary penalties in proportion to the severity of the crime ${ }^{47}$ or

canons imposing power constraints on the political ruler to violate individual rights: the imām may not take anything from the possession of an individual unless there is a well-known entitlement to do so $^{48}$ and

canons directing executive officials to operate on the principle of the public interest (maslaha): [government] relations with the people should be based on the public interest ${ }^{49}$.

\section{Structural canons}

A final category is structural canons. In Islamic law, even more than in systems with constitutionally separated powers like that of the U.S., these canons must do work to apportion institutional responsibilities to the main actors in medieval Muslim

46 For general discussion of the phenomenon (albeit without explicit reference to legal canons), see, for instance, Mathieu Tillier, Les Cadis d'iraq et l'etat abbasside (132/750-334/945)(Damascus: Institut Français du Proche-Orient, 2009), 138-86. Such rules typically appear in judicial conduct literature (adab al$q \bar{a} d \bar{\imath})$ and in judicial biographies (akhbār al-qudāt). al-sulțān).

47 Maḥmașānī, Falsafat al-tashrī', 255-56 (jawāz al-tashrī' min qibal

48 Būrnū, Mawsū'a, 52-53; Maḥmașānī, Falsafat al-tashrī', 255-56 (jawāz al-tashrī' min qibal al-sulțān).

49 Mecelle, art. 58 (al-tașarruf 'alā al-ra iyya manüt bil-mașlaha). 
societies: jurists, judges, and caliphs. That is, jurists use legal canons specifically and interpretation more broadly to allocate power. ${ }^{50}$ Examples from Islamic history abound, and they reflect the unique features of Islamic law's system of legal pluralism and its diffused structures. One example will suffice: a decision based on judicial interpretation cannot be reversed simply by a different interpretation. ${ }^{51}$ Medieval Muslim judges and jurists used this judicial finality canon, and others like it, to define the powers of the courts and other institutions.

A final question to consider on defining legal canons-as-memes, which will be essential to determining their most likely meme-pool in which to search for them is this: Where do these canons come from? The short answer: everywhere that you see texts of law and records of legal history (from both literary and documentary evidence), you are likely to see legal canons. From a jurist's perspective, canons come from three distinct sources, and accordingly they can be found in the doctrinal legal texts (fiqh treatises, canons collections, fatāw $\bar{a})$ : (1) textual-source canons: canons that restate foundational texts (textual-source canons); (2) canons that restate legal principles purportedly based on consensus or formal legal reasoning (interpretive-source canons); and (3) canons that restate legal principles derived by means of equitable principles such as istiḥsān, iștilāh, and istiṣhāb (what we can call equity canons). ${ }^{52}$ But from a historian's bottom-up perspective, these same canons

50 In American law, judges use these canons to play a role in allocating institutional responsibilities substantively "in the ongoing elaboration of statutory schemes," and "courts play a more important role in assuming, assigning, or arbitrating institutional responsibilities." Eskridge, Interpreting Law, 12. Compare Jane Schacter, "The Changing Structure of Legitimacy in Statutory Interpretation," Harvard Law Review 108 (1995): 593-663.

51 Būrnū, Mawsū 'a, 28 (al-ijtihād lā yunqaḍ bi-mithlih), 39 (fa-lā yumkin an tustaqarr al-ahkām); Mecelle, art. 16 (al-ijtihād la yunqaḍ bi-mithlih); see also Kamali, "Legal Maxims," 90.

52 See Būrnū, Mawsū 'a, 32-35, dividing legal canons along three different axes: (1) according to their degree of generality or specificity - into al-qawā 'id al-kulliyya al-kubrā, al-qawā id al-fiqhiyya [al-aghlabiyya], dawābit (pp. 32-35), (2) according to their relationship to the other two principal legal genres - into qawa id usüliyya and qawāid fiqhiyya (pp. 25-28); and (3) according to their known sources - i.e., textual sources (pp. 36-39), interpretive sources that rely on the foundational texts (pp. 39-40), and interpretive sources (pp. 40-41). 
are not so neatly limited and appear regularly in historical chronicles, prosopographical sources, works of literature and more. This fact brings us to the third and final peg of the stool to support the idea of legal canons-as-memes: the legal canons meme pool, which-given the different perspectives of law and history - must include both legal-doctrinal and social-historical sources.

\section{Islamic LaW's Meme Pools: Legal \& Historical Sources}

Now how do legal canons-as-memes relate to sources for law and history? If canons historically represent the individual, perpetuating memes that jump from one jurist, or executive official, or administrator to another, then to evaluate them requires looking at the entire meme pool. If interested in tracing canons through the textual sources that comprise the legal-doctrinal and social-historical written record for this field, then the memepool comprises them all: works of fiqh, ușūl al-fiqh, qawā id fiqhiyya, as well as ta'rīkh chronicles, țabaqāt, adab and more. If we could search all of those sources for the same pat phrases (and close variants) that make up legal-canons-as-memes, then we could begin to trace their origin, spread, function, values, and social phenomena that each reflect, over time, and place. We need not, and should not, divide the study of Islamic legal history into doctrinal-intellectual history and social history by virtue of needing to choose just one of those sets of sources. We are developing new modes of technology to do just that in a soon-to-launch project called CouRTS \& CANONS at Harvard Law School.

Take just one example that appears in several historical chronicles,${ }^{53}$ but never in the works of law that I argue respond

53 See, e.g., Ibn al-Furāt's detailed account in Ta'rīkh duwal walmulūk; Ibn 'Abd al-Z̄āhir, al-Rawḍ al-zāhir, ed. 'Abd al-'Azīz al-Khuwaytir (Riyadh, 1396/1976), 182; Ibn Kathīr, Bidāya, 13:234; Maqrīzī, Sulūk, 1:472. For discussion, see Yossef Rapoport, "Legal Diversity in the Age of Taqlīd: The Four Chief Qāḍīs under the Mamlūks," Islamic Law and Society 10, no. 2 (2003); Sherman A. Jackson, "The Primacy of Domestic Politics: Ibn Bint Al-A'azz and the Establishment 
to them. We begin with the Mongol invasion to Baghdad that ended the Muslim caliphate in 1258. Two years later, in nearby Egypt, a slave soldier (mamlūk) by the name of al-Zāhir Baybars defeated the Mongols in 658/1260, and immediately seized the throne. ${ }^{54}$ To solidify his hold on power and territory, he re-installed a pseudo-caliph whom he "represented." He spent the next few years fighting Crusaders, raising revenue, and setting up a military regime with slave-soldiers at the top: the Mamlūks. Five years in, once he had a hold on power, he turned to domestic affairs: namely questions of law and religious legitimacy. He had initiated some tentative reforms in 660/1262, but it was not until 663/1265 that he ordered a major judicial overhaul.

Each week, Sultān Baybars held court at the "Palace of Justice" that he had constructed just outside the Citadel in the new capital city of Cairo. He used to sit with his top military officials alongside the single chief judge of the realm, a Shāfi ${ }^{\prime} \bar{\imath}$ judge by the name of Ibn Bint al-A'azz (d. 695/1296). On one occasion, in the year 663/1265, two litigants sought resolution of a matter that was ostensibly a private dispute about trusts and estates. But it turns out to have been about much more and precipitated a reform of the entire judiciary.

The facts of the case and the direct legal issue at hand were fairly straightforward. The daughters of the military officer [Amīr Nāṣir] were heirs to his estate. They claimed to have bought a large house from a judge. But when that judge

of the Four Chief Judgeships in Mamluk Egypt," Journal of the American Oriental Society 115, no. 1 (1995); Jørgen S. Nielsen, "Sultan Al-Zāhir Baybars and the Appointment of Four Chief Qāọīs, 663/1265," Studia Islamica 60 (1984): 167-78. This simplified account is drawn from these sources.

54 See further Amalia Levanoni, "The Mamlūks in Egypt and Syria: The Turkish Mamlūk Sultanate (648-784/1250-1382) and the Circassian Mamlūk Sultanate (784-923/1382-1517)," in The New Cambridge History of Islam: Volume 2: The Western Islamic World, Eleventh to Eighteenth Centuries, ed. Maribel Fierro (Cambridge: Cambridge University Press, 2010), 238-39; Sherman A. Jackson, Islamic Law and the State: The Constitutional Jurisprudence of Shihāb Al-Dìn Al-Qaräfì, Studies in Islamic Law and Society V. 1 (Leiden: E.J. Brill, 1996), 42-43, 48; Nasser O. Rabbat, The Citadel of Cairo: A New Interpretation of Royal Mamluk Architecture (Leiden: Brill, 1995), 54, 90-96, 98 and passim; Carl F. Petry, The Civilian Elite of Cairo in the Later Middle Ages, Princeton Legacy Library (Princeton: Princeton University Press, 1981), 15-36. 
died, his heirs claimed that before he died he had converted the property into a charitable trust (waqf), and bequeathed it to his children. So the basic question was: who was entitled to the property or its proceeds: the heirs of the judge or the heirs of the military officer? A senior military officer present at the royal court raised objections to conferring property on the judge's heirs. The chief judge responded with a vague platitude: something to the effect that there are complicated factors in every case. And he advised giving the property to the judge's heirs, and reimbursing the heirs of the military officer for the alleged sale only if they could prove that a sale had occurred. This was a fine point of interpretation: waqf over sale; possession over claims of ownership. [These were two canons, arguably implied in the text.] These presumptions favored the heirs of the judge, and they could only be overcome by clear evidence in the form of two witnesses or a document of sale. Either way, the judges' heirs would win: They would keep the proceeds from trust and only reimburse a portion of it (i.e., the amount of the property sale) in the unlikely event that a military officer's heirs could provide evidence of a sale.

The point of this story is not what actually happened. Instead, it is the scope of judicial power and the chief judges' ability to use canons and interpretive tools to render a singular opinion that arrived at an outcome contrary to what the sultān wanted, with no recourse left to the sulțancouched in the law. Mamlūk chroniclers of the time, and following them, legal historians of this period, point to this case as the acute incident that sparked Sulțān Baybars' major judicial reform. ${ }^{55}$

Sulțān Baybars reformed the judiciary in several ways, starting by weakening the power of the single chief judge - who belonged to the Shāfi ${ }^{\prime} \bar{l}$ legal school-and distributing judicial responsibilities to the other three mainstream legal schools (which he designated as such for the first time to make four state-recognized Sunnī schools of law). He appointed one chief judge for every major approach to Islamic law at the time, that is, for every major school of law (madhhab); and made the

55 See sources cited above, note 37. 
Shāfi ${ }^{\prime} \overline{1}$ judge first among equals in coordinating between them. To put that in modern terms: Chief Judge Ibn Bint al-A 'azz had become the John Roberts of his day, that is, if we too had a system of appointing one originalist, pragmatist, textualist, etc. - one judge for every major interpretive approach or 'school' of law. Finally, he required every school to convene separate court that limited judges' rulings to the existing rules and canons of each school-which jurists then accordingly had to document.

The aftermath was a rise of legal canons literature (among other things). That is, the judicial reform reported had effects on the legal literature and court practice, both of which are well-encapsulated in many of the legal canons collected in their wake. This episode in other words, inadvertently, sparked the rise of legal canons literature: collections of legal canons, by school, from the first five or so centuries of Islamic rule. Of course the initial set of collected legal canons arose out of disputes (common-law style) during Islam's founding period, long before jurists began to collect them by school, en masse, in the wake of Sultān Baybars's reform. Those founding-era legal canons spanned the gamut of legal questions, and they appeared in a wide range of sources for Islamic law and judicial practice: works of substantive law, legal theory, judicial procedure manuals, biographical dictionaries, historical chronicles, literary works, and more (though one question that remains unclear is from which sources the jurists collected them-one question a COURTS \& CANONS tool can help answer). ${ }^{56}$

\section{Conclusion}

With the rise of legal canons collections, the question then becomes: how did these canons operate among judges and jurists and, how did the various actors who we know to have forum-shopped for desired outcomes know which court to go to

56 See Intisar A. Rabb and Bilal Orfali, "Islamic Law in Literature: Some Contributions from Qāụī Tanūkhī," in Arabic Literary Culture: Tradition, Reception, and Performance, eds. Margaret Larkin and Jocelyn Sharlet (Wiesbaden: Harrassowitz, forthcoming 2019); see also my Doubt in Islamic Law. 
for which issue? How did political, economic, and social change or upheaval affect the use, popularity, or expansion of legal canons and the public values they represented? On this point, I invite any scholar interested in the multivariate and rich history of legal canons (as memes) to join a growing effort to explore them through examining both legal and historical sources as the meme pool through which we can answer such questions, and more.

Given all the talk in Islamic law circles about legal history as social history vs. doctrinal history, those writing in the field have come to refer to doctrinal history from sources of law (fiqh, hadīth, etc.) as contrasted with textured history of what happens on the ground ( $t a^{\prime} r \bar{\imath} k h$, țabaqāt, etc.). In fact, this contrast has emerged as a big theme of this Roundtable. Take just a few examples: Legal history appears with a focus on doctrinal sources as Robert Gleave points to critiques of overly law-focused studies of Islamic history, but implores scholars to include often sidelined sources for Shī'i law; as Marion Katz points out that fur $\bar{u}$ ' works proportionally constitute the most under-studied genre in the study of Islamic law [I think canons might give fur $\bar{u}$ ' a run for their money on this bet], and outlines ways to remedy the situation; and Hiroyuki Yanagihashi explores the promise of quantitative methods on hadith texts to match one of the purportedly raw sources of Islamic law with fiqh. Legal history appears with a focus on chronicles, documents, biographical and other sources from all the scholars calling themselves social historians or scholars of early Islam: Najam Haider models how he pairs legal texts for elements of social history with literary narratives to interrogate questions of identity in early Islam; Marina Rustow shines a light on non-legal documents that she used to "write history from the ground up" and to shed light on laws, societies, and institutions; and Elizabeth Urban argues for a multi-genre approach to law and history based on perspectives of vulnerable populations.

And of course most scholars taking part in this Roundtable [including those above] take a capacious view of law and legal history - seeing it as both social and doctrinal. Yossef Rapoport 
explicitly notes that law is inseparable from society as he points to the use of historical sources for the social sphere; Maribel Fierro points out that fiqh was the most prevalent discipline in al-Andalus, but that it appeared alongside at least 12 other types of non-law sources - all yet to be analyzed together. I adopt this view. At the end of the day, all of us are asking timely questions about method and meaning in Islamic law and history in ways that I tried to outline in the introduction to this fantastically enriching exchange. Collectively scholars taking part in this Roundtable have wonderfully displayed multiple approaches to examining law in social-historical context (meaning) and the range of literary, documentary, and computational sources used to address them: which, how, and why (method).

Like other scholars interested in Islamic legal history, I'm interested in both method and meaning and propose using legal canons to explore them. Can we meaningfully explore both social-historical and legal-doctrinal sources, for how law [through meme-like legal canons] reflects society and how society reflects aspects of law? Can new collaboratively-built data science / digital humanities tools aid us in doing? Can we somehow harness the voluminous records and individual areas of expertise that tend to make many scholars focus study on only one area at a time, social-historical vs. legal-doctrinal? In my view, the answer is "yes" to all of these questions, when thinking of canons as memes. It turns out that canons are memes perfectly well-suited to quantitative analysis, supplemented by qualitative-historical analysis, and can offer means of gaining special insight into the social history of Islamic law, provided we can construct a meme pool that includes both historical and legal sources.

Here are three ways that I think this can work, and a few thoughts on to what end:

Legal canons, by definition and through frequent-repetition, are anonymized reports that take on a life of their own, replicate, and evolve in different incarnations - some viral, others contained; some fleeting, some long lasting. We hope to collect and assess canons in the new COURTS \& CANONS platform at 
Harvard Law School [access forthcoming], which now provides a data entry tool to capture and code the key features of canons, and at later stages will deploy AI tools to automatically search for and capture canons according to those very features.

As memes, legal canons can be tracked in a meme pool of historical and legal sources. Such a meme pool can offer a means of "memome mapping" through exploring individually owned corpora, library corpora, or the growing corpus at OpenITI through the KITAB project [up to 6000 texts with its recent release] (a joint effort of and Matthew Miller, Maxim Romanov, and Sarah Savant).

Thinking of legal canons as memes that transform through mutation, once we've collected a basic list of representative canons, we can do "fuzzy" semantic searches for variant legal canons to find both exact phrases and variants everywhere they appear in the meme pool of historical and legal texts. Mairaj Syed showed a sample of this last year with his NLP experimental analysis of the doubt canon and evidence canon on this Blog. On the latter point, in addition to considering and categorizing canons individually, it is important to keep in mind that canons come with variants, hierarchies, and contests or "duels" that make them hard to define collectively in ways that mirror the definitional problems of legal canons elsewhere. That is, sometimes canons are variants of one another known differently to different schools of law. Sometimes they fall into a hierarchy or judge-imposed ordering, like debates that unfold in both American and Islamic law over lenity-first versus lenity-last: does the doubt canon or rule of lenity apply only after applying all other canons to clarify the meaning of the law, or before? And sometimes they are contested canons within and among various schools of law, or "dueling canons" where one canon is in direct contradiction with another and judges or jurists must choose which one prevails. Counting canons, assessing their variants, and charting the variants, ordering, and duels are all pressing research questions that we've so far undertaken laboriously in American law, less so in Islamic law, but that can be aided by a database of canons that allows for matching, ordering, and 
contrasting variant or dueling canons..$^{57}$

To what end? With these features in mind, we aim to build a COURTS \& CANONS tool [+ database] that can demonstrate exactly how well suited legal canons are for identification, analysis, and geo-mapping as they copy, mutate, and spread. Legal canons as memes offer observable means of legal propagation and change in various ecosystems, from the seventh century onward; and were self-consciously so beginning in the mid-seventh/thirteenth century as Mamlūk-era jurists began to collect them to form an independent genre, and executives ordered judges to use them. These facts suggest that tracking legal canons-memes through the meme pool of both historical and legal sources with the use of data science can aid research and facilitate new insights that would be difficult or near-impossible with human eyes alone. At a basic level, such tools will allow for counting canons (how many were there, about what subject, to what frequency and why?); mapping canons (how did they spread across schools, geographies, and time, and why?); and interrogating canons by function (what role did they play in interpretation, in allocating institutional power, in the lives of ordinary subjects)? And at a broader level, such legal canons-meme-mapping through a broad meme-pool can reveal how juristic/judicial officials, executive officials, and other members of society either used or disregarded canons; it can

57 For some of the manual collections and definitional problems in American law, see above note 1. To take just one example of canons taken in combination: consider a recent example of dueling canons in Lockhart v. United States, 577 U.S. _ (2016), where the Supreme Court debated whether an adjective following a list applies only to the last item (according to the "rule of the last antecedent") or to all the items in the list (according to the "series qualifier canon"), and ultimately decided in favor of the former and against both the latter and the rule of lenity (and consequently against the defendant) - likely because of the sensitive values at play in a case where the defendant was a convicted sex-offender. Such dueling or qualified canons are precisely the subject of an entire sub-genre of Islamic legal canons, furūq literature, as exemplified in the writings of Qarāfî, Furūq —on which, see Sheibani, "Mamlūk-Era Legal Maxims Collections," esp. 934-41 (discussing contested canons). On furūq as distinctions more generally, see Elias G. Saba, Harmonizing Similarities: A History of Distinctions Literature in Islamic Law(Berlin: De Gruyter, 2019), esp. 16-42; Necmettin Kız1lkaya, İslâm Hukukunda Farklar: Furûk Literatürü Üzerine Bir İnceleme (İstanbul: İz Yayıncılık, 2016); Ya qūb al-Bā Ḥusayn, al-Furūq al-fiqhiyya wa'l-ușūliyya (Riyadh: Maktabat al-Rushd, 1419/1998). 
show whether and how canons coincided with, affected, or were affected by the lives of ordinary people, institutions, and exogenous of events; and-as noted above-mapping canons can show whether and which values account for their perpetuation and role in the history of Islamic law and society. There is much to be done, and to see, here! 